\title{
Role of Secondary Plant Metabolites on Enteric Methane Mitigation in Ruminants
}

\author{
Juan Carlos Ku-Vera ${ }^{1 *}$, Rafael Jiménez-Ocampo ${ }^{1,2 *}$, Sara Stephanie Valencia-Salazar ${ }^{3}$, \\ María Denisse Montoya-Flores ${ }^{4}$, Isabel Cristina Molina-Botero ${ }^{5}$, Jacobo Arango ${ }^{6}$, \\ Carlos Alfredo Gómez-Bravo ${ }^{5}$, Carlos Fernando Aguilar-Pérez ${ }^{1}$ and \\ Francisco Javier Solorio-Sánchez ${ }^{1}$ \\ ${ }^{1}$ Laboratory of Climate Change and Livestock Production, Department of Animal Nutrition, Faculty of Veterinary Medicine \\ and Animal Science, University of Yucatan, Mérida, Mexico, ${ }^{2}$ National Institute for Forestry, Agriculture and Livestock \\ Research-INIFAP, Experimental Field Valle del Guadiana, Durango, Mexico, ${ }^{3}$ College of the Southern Border (ECOSUR), \\ Livestock and Environment, San Cristóbal de las Casas, Mexico, ${ }^{4}$ National Center for Disciplinary Research in Physiology \\ and Animal Breeding, National Institute for Forestry, Agriculture and Livestock Research-INIFAP, Ajuchitlan, Queretaro, \\ Mexico, ${ }^{5}$ Department of Nutrition, Faculty of Animal Science, National Agrarian University La Molina, Lima, Peru, \\ ${ }^{6}$ International Center for Tropical Agriculture (CIAT), Cali, Colombia
}

\section{OPEN ACCESS}

Edited by:

Manuel Gonzalez Ronquillo, Universidad Autónoma del Estado de

México, Mexico

Reviewed by:

Alfonso Juventino Chay-Canul, Universidad Juárez Autónoma de

Tabasco, Mexico Maria Grazia Cappai,

University of Sassari, Italy

${ }^{*}$ Correspondence: Juan Carlos Ku-Vera kvera@correo.uady.mx

Rafael Jiménez-Ocampo rafax77@hotmail.com

Specialty section: This article was submitted to Animal Nutrition and Metabolism,

a section of the journa

Frontiers in Veterinary Science

Received: 09 May 2020

Accepted: 21 July 2020

Published: 27 August 2020

Citation

Ku-Vera JC, Jiménez-Ocampo R, Valencia-Salazar SS

Montoya-Flores MD,

Molina-Botero IC, Arango J,

Gómez-Bravo CA, Aguilar-Pérez CF

and Solorio-Sánchez FJ (2020) Role of

Secondary Plant Metabolites on

Enteric Methane Mitigation in

Ruminants. Front. Vet. Sci. 7:584.

doi: 10.3389/fvets.2020.00584
The rumen microbiome plays a fundamental role in all ruminant species, it is involved in health, nutrient utilization, detoxification, and methane emissions. Methane is a greenhouse gas which is eructated in large volumes by ruminants grazing extensive grasslands in the tropical regions of the world. Enteric methane is the largest contributor to the emissions of greenhouse gases originating from animal agriculture. A large variety of plants containing secondary metabolites [essential oils (terpenoids), tannins, saponins, and flavonoids] have been evaluated as cattle feedstuffs and changes in volatile fatty acid proportions and methane synthesis in the rumen have been assessed. Alterations to the rumen microbiome may lead to changes in diversity, composition, and structure of the methanogen community. Legumes containing condensed tannins such as Leucaena leucocephala have shown a good methane mitigating effect when fed at levels of up to 30-35\% of ration dry matter in cattle as a result of the effect of condensed tannins on rumen bacteria and methanogens. It has been shown that saponins disrupt the membrane of rumen protozoa, thus decreasing the numbers of both protozoa and methanogenic archaea. Trials carried out with cattle housed in respiration chambers have demonstrated the enteric methane mitigation effect in cattle and sheep of tropical legumes such as Enterolobium cyclocarpum and Samanea saman which contain saponins. Essential oils are volatile constituents of terpenoid or non-terpenoid origin which impair energy metabolism of archaea and have shown reductions of up to $26 \%$ in enteric methane emissions in ruminants. There is emerging evidence showing the potential of flavonoids as methane mitigating compounds, but more work is required in vivo to confirm preliminary findings. From the information hereby presented, it is clear that plant secondary metabolites can be a rational approach to modulate the rumen microbiome and modify its function, some species of rumen microbes improve protein and fiber degradation and reduce feed energy loss as methane in ruminants fed tropical plant species.

Keywords: tannins, saponins, essential oils, flavonoids, methane, ruminants 


\section{INTRODUCTION}

A rise in the demand of beef and milk in a time horizon to the year 2050 has been predicted due to increasing population, urbanization and the rise in income by some strata of society (1). In the forthcoming years, ruminant production systems will be affected by occasional shocks such as emerging diseases, trade wars, but more regularly by climate change (causing droughts, floods, etc.), which results from the increasing concentrations of greenhouse gases such as carbon dioxide $\left(\mathrm{CO}_{2}\right)$ methane $\left(\mathrm{CH}_{4}\right)$ and nitrous oxide $\left(\mathrm{N}_{2} \mathrm{O}\right)$ among other gases in the atmosphere. Ruminant production systems contribute significantly to the emissions of enteric $\mathrm{CH}_{4}$ (2) to the atmosphere. Considerable research efforts are being invested in the attempt to mitigate this potent greenhouse gas which is 28 times a higher global warming potential compared to that of $\mathrm{CO}_{2}$ (3).

Tropical pastures are characterized by a high concentration of structural carbohydrates (cellulose, hemicellulose) and low concentrations of crude protein $(\mathrm{N} \times$ 6.25). A fact which constrains anaerobic fermentation of organic matter and induces long retention times of digesta in the reticulo-rumen (4), leading to high emissions of enteric $\mathrm{CH}_{4}$ (5). Under those circumstances, it has been claimed that secondary metabolites contained in a wide variety of plants may mitigate $\mathrm{CH}_{4}$ emissions through a variety of mechanisms involving the rumen microbiome (6-8). Although secondary metabolites may be usually considered beneficial, the concentration of certain ergot alkaloids such as ergosine and ergocristine in pastures may lead to toxicity under certain circumstances in grazing animals such as sheep and horses (9). Maximal anaerobic fermentation of structural carbohydrates in the rumen is paramount in the transit toward sustainable intensification of tropical animal agriculture by extracting the largest possible amount of useful energy from the rumen which is limited thermodynamically (only 4-5 $\mathrm{ATP} / \mathrm{mol}$ glucose fermented), for productive purposes. Rumen anaerobiosis dictates that only a limited amount of ATP can be generated from glucose fermentation to volatile fatty acids, heat, $\mathrm{CO}_{2}$, and $\mathrm{CH}_{4}$ (10). The rumen microbiome is strongly associated to economically and environmental variables which affect feed efficiency and sustainability of ruminant production $(11,12)$. Increasing the flow of $\mathrm{H}_{2}$ in the rumen away from $\mathrm{CH}_{4}$ formation toward propionic acid synthesis increase the efficiency of metabolisable energy utilization at the whole animal level while reducing the environmental impact of animal production. It has been recently demonstrated that propionic acid bacteria increase feed degradability and decrease methane production under in vitro conditions thus shifting the $\mathrm{H}_{2}$ flow away from $\mathrm{CH}_{4}$ synthesis toward propionate formation (13), a gluconeogenic precursor.

Other rumen microorganisms are the anaerobic fungal communities, eighteen species from six genera, including monocentric Neocallimastix, Caecomyces, Piromyces, and the polycentric Anaeromyces, Orpinomyces, and Cyllamyces. These groups of microorganisms serve to expose cellulosic components to bacteria to synthesize VFA, but the relationship of fungal abundance with methane emission is still uncertain $(14,15)$. Rumen metagenome sequencing studies reveal that the higher abundance of Bacteroidetes in the rumen improves feed efficiency, combined with a lower abundance of Firmicutes and methanogenic archaea (16). It has been shown that the reduction of genera such as Methanobrevibacter and Acetobacter are potential targets for the reduction of $\mathrm{CH}_{4}$, on the other hand, an increase in the abundance of the genera Methanosphaera and Eubacterium led to reductions in $\mathrm{CH}_{4}$ emissions in heifers (17). The diversity of the rumen microbiome is related to a myriad of factors such as breed, age, rumen volume and passage rate, geographical location, physiological stage, but essentially to the chemical composition of the ration consumed which is reflected in the resulting pattern of fermentation $(15,18)$. It is in this context, that plant secondary metabolites (PSM) such as tannins, saponins, essential oils, and flavonoids play an important role in the efforts to mitigate the emissions of $\mathrm{CH}_{4}$ from ruminant species. There is a large number of shrub and trees, both legume and non-legume species with great potential for ruminant production in the tropics (19-21) among them, Leucaena leucocephala is one of the most promising (22), which contain a wide variety of secondary compounds (2327) with potential methane-suppressing properties. Secondary metabolites display different mechanisms of action either direct or indirect on the ruminal fermentation and rumen microbiome which decreases $\mathrm{CH}_{4}$ synthesis, but an important factor to consider is the persistency of the effect. The aim of the present review is to critically examine the mechanisms of action of secondary compounds contained in a number of tropical plant species on $\mathrm{CH}_{4}$ mitigation in ruminants.

\section{METHANE SYNTHESIS}

Ruminants are herbivorous that maintain a symbiotic relationship with a large consortium of microorganisms which inhabit the reticulo-rumen. The rumen microbial ecosystem has not been fully studied; therefore, it is difficult to understand all the mechanisms of its functioning, complexity, and interaction among the microbes (28). In the rumen, protozoa, bacteria, and fungi communities ferment enzymatically structural carbohydrates, starch, and proteins. During the fermentation process, volatile fatty acids (VFA), $\mathrm{CO}_{2}$, and metabolic $\mathrm{H}_{2}$ are produced and used by methanogenic archaea for the synthesis of $\mathrm{CH}_{4}$ (7). Methanogenic archaea fluctuate between $10^{7}$ and $10^{9}$ cells per milliliter of rumen fluid (29) and approximately two thirds belong to the genus Methanobrevibacter and Methanosarcina (30) representing $1-4 \%$ of the microbial biomass. Protozoa use starch, cellulose, hemicellulose, pectin, and soluble sugars to produce VFA and metabolic $\mathrm{H}_{2}$ that is used by the archaea that are attached to its surface to produce $\mathrm{CH}_{4}$ (31); thus, there is an association between archaea and the protozoa in the rumen $(26,32)$. Archaea produce $\mathrm{CH}_{4}$ as a metabolic strategy to obtain the energy necessary for their growth (33). Rumen methanogens use the $\mathrm{H}_{2}$ resulting from the fermentation of carbohydrates to reduce $\mathrm{CO}_{2}$ to $\mathrm{CH}_{4}$ in a series of biochemical reactions coupled to ATP synthesis, where $\mathrm{CO}_{2}$ is used as a carbon source and $\mathrm{H}_{2}$ as the main donor of electrons. In this process, 4 moles of $\mathrm{H}_{2}$ are used to produce one 
mole of $\mathrm{CH}_{4}$ (34). The chemical reaction for methane synthesis is $\mathrm{CO}_{2}+4 \mathrm{H}_{2} \rightarrow \mathrm{CH}_{4}+2 \mathrm{H}_{2} \mathrm{O}$.

Methanogenesis is the main biochemical pathway for the removal of metabolic hydrogen released from fermentation of carbohydrates in the rumen. A decrease in $\mathrm{CH}_{4}$ synthesis would be achieved by inhibiting $\mathrm{H}_{2}$-releasing reactions or promoting alternative pathways, where $\mathrm{H}_{2}$ is removed during fermentation. The rate of methane production in the rumen depends particularly on the composition of the ration, being the type carbohydrate (cellulose vs. starch), protein and lipids, the components that most influence exert $(26,35)$, but also on physiological factors such as retention time of digesta in the rumen. The main factor from the ration determining methane synthesis in the rumen is the type of carbohydrate fermented, either structural (cellulose, hemicellulose) typical of forage rations or non-structural (starch, soluble sugars) characteristic of grain (concentrate) rations. The type of carbohydrate being fermented in the rumen also dominates the composition of the rumen microbiome (cellulolytic, amylolytic, pectinolytic, types of bacteria).

Methane is a gas produced in the rumen and is continuously emitted throughout the day; mostly eructated to the atmosphere by the mouth and to a lesser extent by the nostrils (and the anus). $\mathrm{CH}_{4}$ has a heat of combustion of $892.6 \mathrm{~kJ} / \mathrm{mol}$ (i.e., $55.65 \mathrm{MJ} / \mathrm{kg}$ ) (36) and represents an energy loss (3-12\% of gross energy intake) for the animal. There is considerable potential to manipulate the fate of metabolic hydrogen in the rumen, away from methane synthesis toward propionic acid formation which consumes the hydrogen available, by feeding plants containing secondary metabolites to ruminants. Methanogenesis is the main molecular $\mathrm{H}_{2}$ sink in the rumen and the partial pressure of $\mathrm{H}_{2}$ thermodynamically controls the oxidation-reduction state in this organ for fermentation to proceed for the synthesis of volatile fatty acids, heat, and microbial matter (37). Propionic acid is the only gluconeogenic volatile fatty acid with potential to improve the efficiency of utilization of metabolisable energy in the whole animal for productive purposes (38). The challenge ahead for the development of low-emission animal production systems lies in inducing changes in the rumen microbiome by feeding plants containing secondary metabolites, which will induce alterations in rumen fermentation, rechannelling $\mathrm{H}_{2}$ into more energetically efficient biochemical pathways (i.e., VFA synthesis: propionate) which will concomitantly decrease $\mathrm{CH}_{4}$ formation.

\section{PLANT SECONDARY METABOLITES FOR THE REDUCTION OF METHANE SYNTHESIS}

PSM have long been considered important for their protective role against plant predators, their synthesis is regulated by environmental, seasonal, or external stimuli. For years, secondary metabolites have been considered toxic to animals and they were termed anti-nutritional factors (39). However, in the last few decades those metabolites have gained growing interest in animal nutrition due to their beneficial effect for the control of parasites, rumen fermentation, and methane synthesis reduction.
PSM possess ample biological activity in ruminal fermentation processes involved in herbivory and also by their potential to affect growth rate of the rumen microbial population so as to provoke changes that induce mitigation of enteric $\mathrm{CH}_{4}$ emissions in ruminants $(27)$. Tannins $(8,40)$, saponins $(25,41)$ essential oils $(24,42)$, and flavonoids $(41,43)$ have all been evaluated in their potential for enteric $\mathrm{CH}_{4}$ mitigation in ruminants. Frequently, their effects on the rumen microbial population are indirect rather than direct. Plants may have a wide variety of secondary metabolites in large or small quantities which may determine their effect on rumen microorganisms. Table 1 describes the effect of PSM on methane production and Table 2 show the effect of secondary metabolites on the microbial population.

\section{TANNINS}

Tannins belong a subclass of plant polyphenols (8). Tannins can be divided in hydrolysable and condensed tannins which have different chemical structures (66). Hydrolysable tannins usually contain a polyol core molecule, usually glucose, but also other core molecules such as: glucitol, hammamelose, shikimic acid, quinic acid, and quercitol. On the other hand, condensed tannins distinguish themselves from other polyphenols by their capacity to form complexes and precipitate proteins. They are proanthocyanidins consist of oligomers or polymers of flavan-3-ol subunits (67). Condensed tannins are the secondary metabolites more studied in terms of methane mitigation compared to hydrolysable tannins. Figure 1 illustrates the chemical structure of common condensed and hydrolysable tannins.

Tannins have the capacity to reduce methane synthesis in the rumen directly or indirectly by either inhibiting methanogens or protozoal population, respectively. There are several possible hypotheses to explain the mechanisms of action of tannins on enteric $\mathrm{CH}_{4}$ mitigation (40). One of them suggest a direct effect of condensed tannins on rumen methanogenic archaea by binding the proteinaceous adhesin or parts of the cell envelope, thus impairing the establishment of the methanogenprotozoa complex and decreasing interspecies hydrogen transfer and inhibition of methanogen growth (68). Another possible explanation is by indirect inhibition by reducing the availability of nutrients (i.e., carbohydrates, amino acids) to rumen microorganisms, tannin-protein complexes are formed at in the rumen and that postruminal $\mathrm{pH}$ shifts in the abomasum $(\mathrm{pH}$ $<3.5)$ and the small intestine $(\mathrm{pH}>7)$ release protein from these complexes, thus making it available for gastric digestion (69), thus reducing digestibility of feed, and impairing the rumen microbial population. A last theory proposes that condensed tannins act as hydrogen sink themselves diminishing their availability for carbon dioxide reduction to methane, implying that $1.2 \mathrm{~mol}$ methane is reduced per mol of catechin (i.e., $6 \mathrm{H}_{2}$ atoms per molecule of catechin) (40).

Crossbred cows fed a mixture of a low-quality tropical grass (Megathhyrsus maximus) and increasing levels of chopped legume leaves of Leucaena leucocephala, and housed in opencircuit respirations chambers decreased methane production (44) 
TABLE 1 | Effect of plant species or plant extracts containing secondary metabolites on enteric methane mitigation in ruminants as measured in open-circuit respiration chambers in tropical regions.

\begin{tabular}{|c|c|c|c|c|c|c|c|c|}
\hline References & Scientific name & Family & Part of plant & Tannins & Saponins & $\begin{array}{l}\text { Essential } \\
\text { oils }\end{array}$ & Flavonoids & $\begin{array}{c}\text { Methane mitigation (\%) } \\
\text { over control ration }\end{array}$ \\
\hline \multicolumn{9}{|c|}{ Secondary compounds } \\
\hline (44) & $\begin{array}{l}\text { Leucaena } \\
\text { leucocephala }\end{array}$ & Fabaceae & Forage & + & & & & 20 \\
\hline (45) & Samanea saman & Fabaceae & Pods & + & + & & & 50 \\
\hline (46) & $\begin{array}{l}\text { Enterolobium } \\
\text { cyclocarpum + } \\
\text { Gliricidia sepium }\end{array}$ & Fabaceae & Pods + forage & + & + & & & 6.3 \\
\hline (47) & $\begin{array}{l}\text { Fagopyrum } \\
\text { esculentum }\end{array}$ & Polygonaceae & Rutin & & & & + & 0 \\
\hline (48) & $\begin{array}{l}\text { Leucaena } \\
\text { leucocephala }\end{array}$ & Fabaceae & Forage & + & & & & 14 \\
\hline (49) & Termalia chebula & Combretaceae & Seed pulp & + & & & & 13 \\
\hline (49) & Allium sativum & Amaryllidaceae & Bulb & + & & & & 2.5 \\
\hline (50) & $\begin{array}{l}\text { Mimosa } \\
\text { caesalpiniaefolia }\end{array}$ & Fabaceae & Forage & + & & & & 31.2 \\
\hline (50) & Eucalyptus spp. & Myrtaceae & Oil & & & + & & 30 \\
\hline
\end{tabular}

as the level of leucaena intake was increased from 0 to $36 \%$ of ration DM. Leucaena leucocephala is a legume species widely distributed in Latin America and The Caribbean regions, which is commonly fed to cattle by farmers (70). The reduction up to $20 \%$ in methane emissions, agrees with previous work carried out with cows fed Leucaena leucocephala in Colombia (48) and in grazing cows consuming leucaena pastures in Australia (71). It is likely that under those conditions, condensed tannins in the legume had an effect on the rumen microbial population reflected in methane reduction. It has been considered that high molecular weight CT fractions of Leucaena leucocephala have higher protein-binding affinities compared to low molecular weight fractions, therefore the effect may be associated to the binding ability to cell membranes, resulting in the prevention of nutrient transport into the cell and inhibition of microbial growth (72).

Other tropical legumes such as Desmanthus spp. have also induced a reduction in enteric $\mathrm{CH}_{4}$ emissions in cattle grazing tropical pastures (73). In India, Pal et al. (74) studied a range of tree leaves containing different concentrations of condensed tannins, demonstrating the strong relationship between tannin content in leaves and methane mitigation under in vitro conditions. Condensed tannins (17.2\%) and saponins (10.9\%) from mangonsteen peel offered at $100 \mathrm{~g} /$ head/day to swamp buffaloes increased total bacteria population and $R$. flavefaciens while methanogens were decreased $(p<0.05)$ (51). Another study reported a reduction in methane production of up to $25 \%$ with mangosteen peel and garlic pellet (75). Acacia cyanophylla in an in vitro study supplemented at 60 and $30 \%$ reduced 37.5 and $56.2 \% \mathrm{CH}_{4}$ production, respectively due to the high content of condensed tannins that reduced archaea (76).

\section{SAPONINS}

Saponins are high molecular weight glycosides, with a sugar linked to a hydrophobic aglycone (Figure 2). They usually occur as glycosides of steroids or as polycyclic triterpenes. Saponins can be generally classified as steroidal and triterpenoid (77). Saponins are present in a wide variety of tropical trees and shrubs and ruminant species eagerly consume their foliage or pods while browsing. It is generally considered that their main biological effect is on cell membranes. Saponins have been described to be toxic to protozoa (25) and it has been suggested that methanogenic archaea are symbiotically associated to rumen protozoa.

Saponins have the capacity to form complexes with the lipid membrane of bacteria, which increases their permeability, generating an imbalance, and consequently lysis of the microorganism, most of the saponins have an effect on protozoa (78). Wallace et al. (79) proposed that saponins may disrupt protozoa by forming complexes with sterols in the protozoal membrane surface which then becomes impaired and disintegrate. In addition, some saponins have influence on different types of membrane proteins such as $\mathrm{Ca}^{2+}$ channels and $\mathrm{Na}^{+}-\mathrm{K}^{+}$ATPases (80). Ramos-Morales et al. (81) proposed that the effect of saponins on protozoa is temporary due to the fact that bacteria may degrade saponins into sapogenins, a compound that cannot affect protozoa. Wina et al. (82) suggested that protozoa are able to produce extracellular polysaccharides around the membrane to avoid its degradation. In addition, protozoa, depending on the dose and type of the saponin fed, can be reduced in the long term or adapt to the metabolite in the short term (82).

Samanea saman (rain tree, in Spanish: algarrobo, genízaro) is a tropical legume present in Mexico, Central America and northern countries of South America as well as Asia and Africa. It contains crude protein and fermentable sugars, the pods fall during the dry season and they are directly consumed by cattle (83). Anantasook et al. (52) supplemented ground pods of Samanea saman (rain tree) containing tannins and saponins to rumen-cannulated dairy steers fed a basal ration of urea-treated rice straw and found a reduction in methane emissions also 
TABLE 2 | Effect of secondary metabolites on rumen microorganisms.

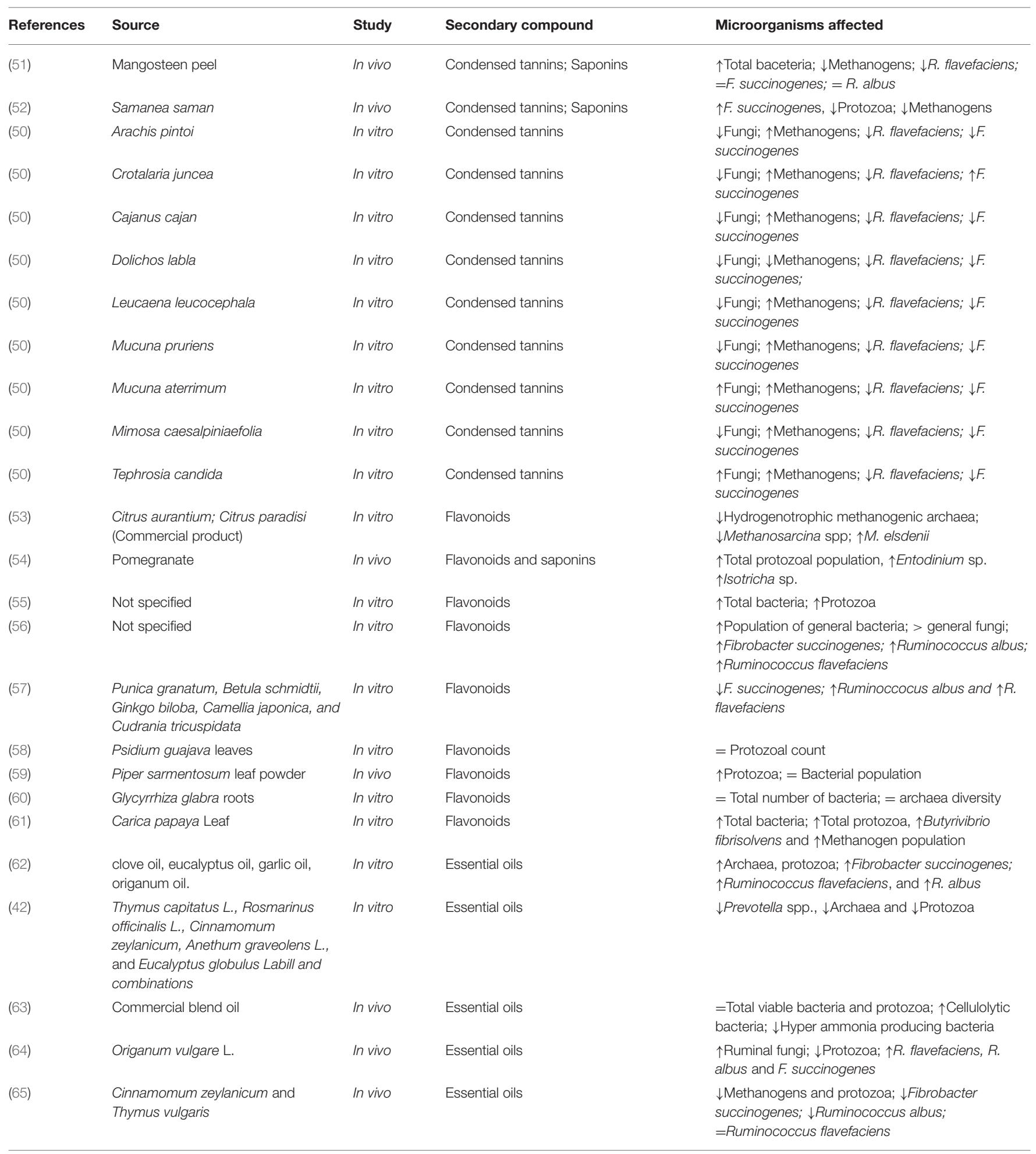

in the protozoal population while propionic acid concentration in the rumen was increased. They concluded that saponins in Samanea saman contributed to alter the rumen microbiome by decreasing protozoa and probably methanogenic archaea with the resultant decrease of up to $50 \%$ in $\mathrm{CH}_{4}$ synthesis. ValenciaSalazar et al. (45) fed crossbred heifers housed in respiration chambers with ground pods of Samanea saman at different levels and demonstrated a reduction in enteric $\mathrm{CH}_{4}$ production of up to 


\section{Tannins}

Hydrolyzable tannin<smiles></smiles>

Condensed tannin

FIGURE 1 | Chemical structure of condensed and hydrolyzable tannins.

$50 \%$ and an increase in propionic acid in rumen liquor, although no effect on the rumen protozoal population was recorded. In this experiment the rechannelling of $\mathrm{H}_{2}$ toward propionate synthesis in the rumen, was the most plausible explanation for the decrease in methane emissions.

Foliage and pods (45) of Samanea saman show good potential to mitigate enteric methane emissions under practical conditions in farms as part of the ration of grazing ruminants, particularly during the dry season. Similarly, Enterolobium cyclocarpum (in Spanish: guanacaste, parota) is a tropical tree which produce foliage and pods which can be employed in ruminant feeding. It is widespread in Central and northern South America and also in Africa (Nigeria). The seeds contain starch (84) and the ground pods of Enterolobium cyclocarpum can be readily incorporated in the rations of sheep at levels of $32 \%$ (85) and up to $50 \%$ (86) with good results in terms of liveweight gain. It has been studied in Canada $(87,88)$, in Switzerland $(89,90)$ and in the United Kingdom (91) because of its methane-suppressing properties. It seems the saponins contained in the foliage of Enterolobium cyclocarpum affect rumen protozoa population in a selective form $(87,88)$. The foliage is readily consumed by goats (92). Albores-Moreno et al. (93) found that supplementation of hair sheep with ground pods of Enterolobium cyclocarpum (36\% DM) decreased enteric methane emissions (estimated by fermentation balance stoichiometry) and the protozoa population, probably as a result of the effect of saponins on the membrane of some protozoa species.

\section{ESSENTIAL OILS}

Essential oils (EO) are aromatic compounds (Figure 3) largely volatile, which can be found in edible, medicinal, and herbal plants. They are produced in special cells in different parts of the plants, including roots, seeds, fruit, leaves, flowers, bark, petals, and stems (94).

The potential of EO for enteric $\mathrm{CH}_{4}$ mitigation has been revised $(24,91)$. The beneficial effects of $\mathrm{EO}$ on the animal such as antioxidant, anti-inflammatory, immune status, and antimicrobial have been shown against a wide variety of microorganisms either Gram-positive or Gram-negative bacteria, fungi, viruses, and protozoa, but more effective against the Gram positive, because most active compounds present in essential oils are lipophilic. In the Gram-negative type, the aromatic hydrocarbons destroy the external membrane $(94,95)$. This antimicrobial activity is believed to be due to certain terpenoids; 


\section{Saponins}

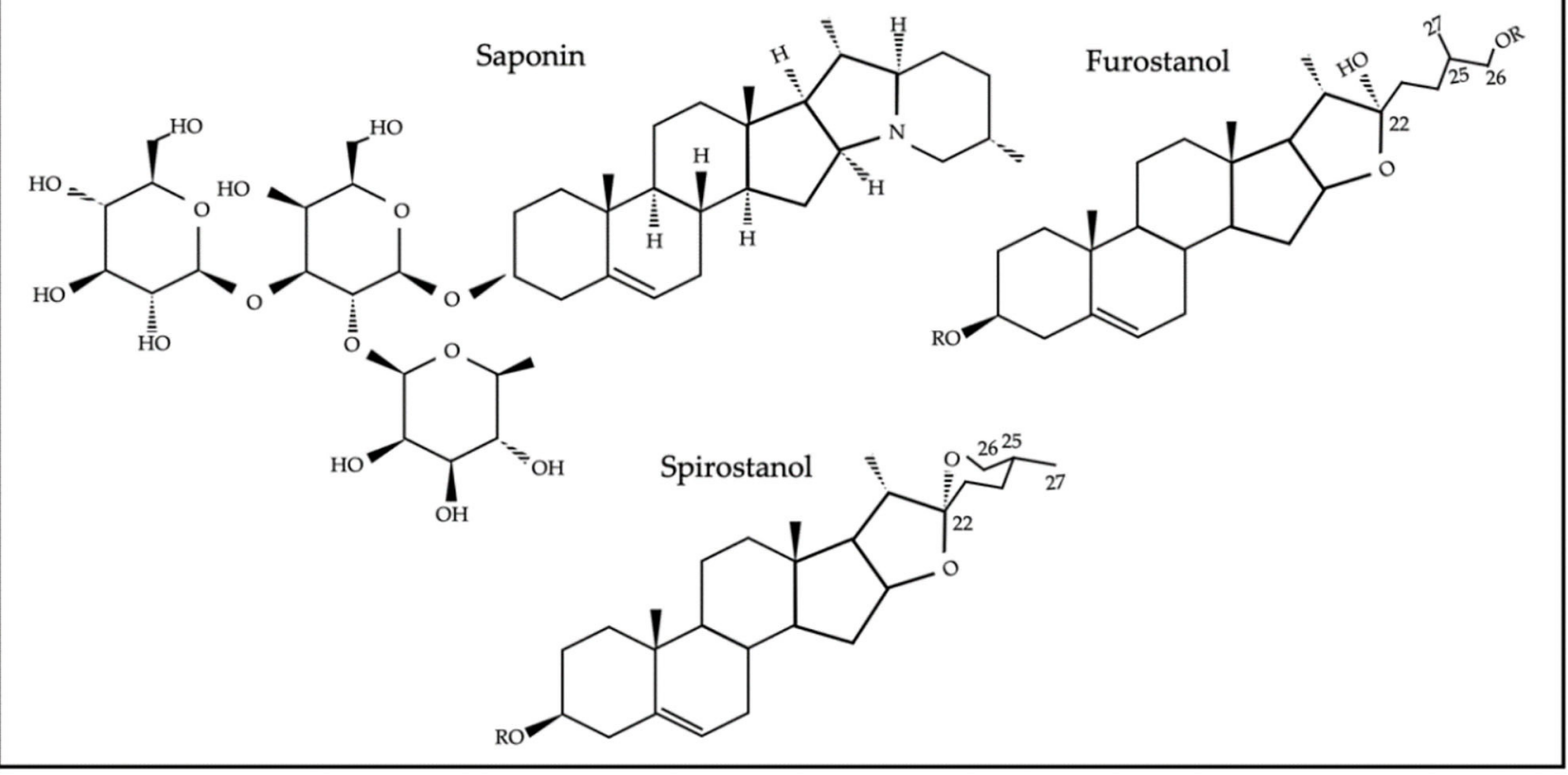

FIGURE 2 | Chemical structure of saponins.

\section{Essential oils}

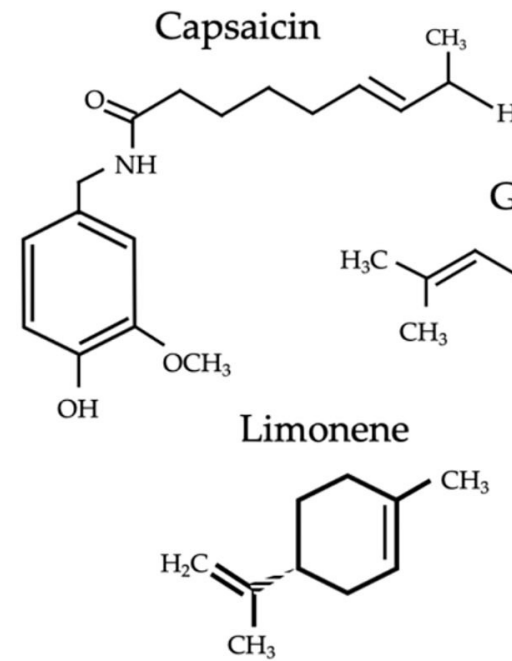

\section{Geraniol}<smiles>CCC(C)=CCO</smiles><smiles>Cc1ccc(C(C)C)cc1O</smiles>

Thymol<smiles>Cc1ccc(C(C)C)c(O)c1</smiles>

\section{Eugenol}<smiles>O=C/C=C/c1ccccc1</smiles><smiles>C=CCc1ccc(O)c(OC)c1</smiles>

FIGURE 3 | Chemical structures of some essential oils.

(15,000 described in the literature) and phenolic compounds but also to other chemical constituents and functional groups contained in essential oils, 20-60 chemical substances such as acids, alcohols, aldehydes, hydrocarbons, ketones, esters, coumarins, and ethers in trace amounts have been identified (96). EO present a high affinity for the membrane cell of bacteria 


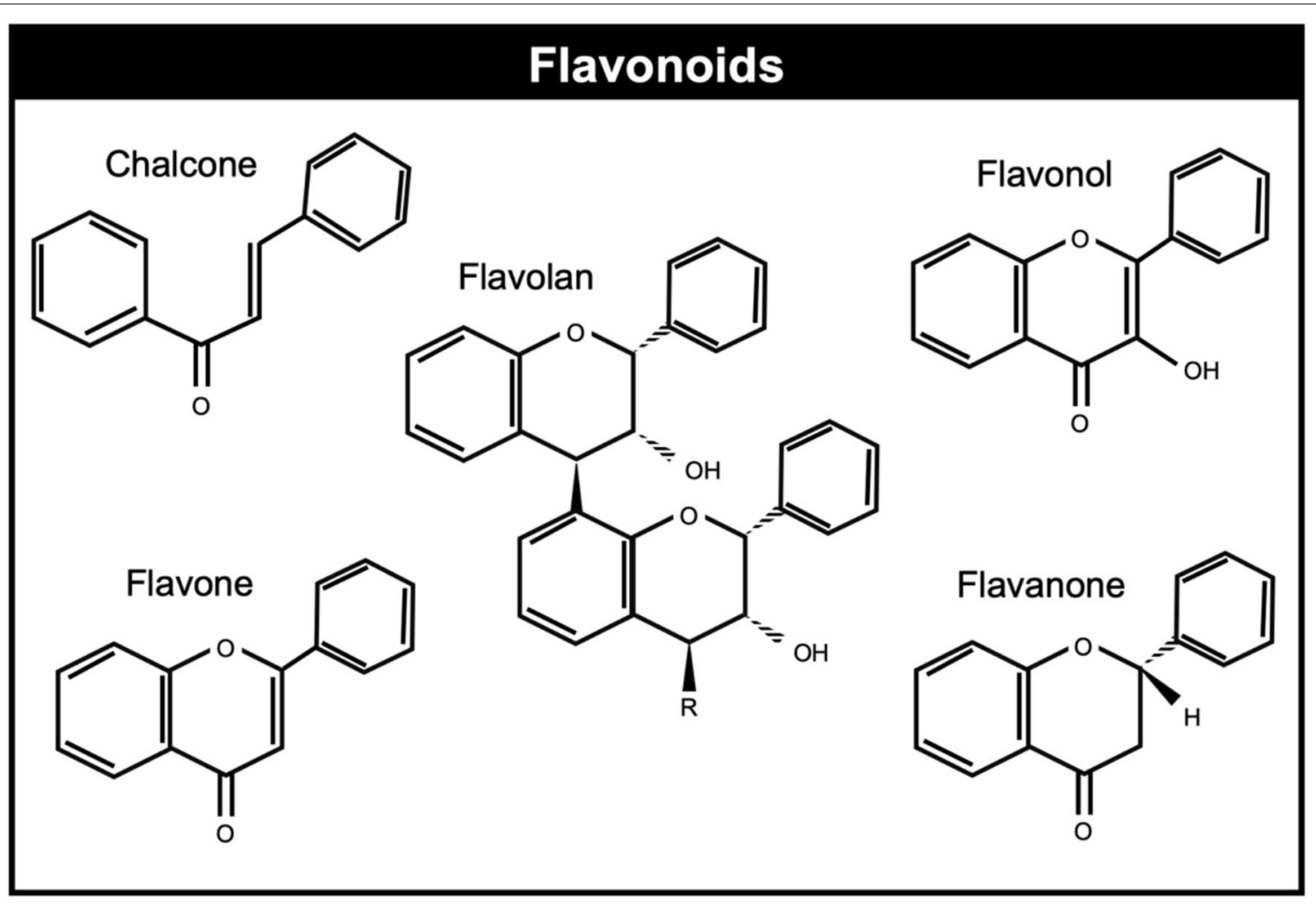

FIGURE 4 | Chemical structures of common flavonoids.

due to their hydrophobic nature and their affinity for lipids which can disrupt the cytoplasmic membrane either directly or by damaging the membrane proteins, provoking increased membrane permeability, conformational changes, leakage of cytoplasmic components, interfering with bacterial growth and activity, causing changes in the rumen population and fermentation profile $(97,98)$.

The antimicrobial action has been related to electron transport, ion gradient, protein translocations, phosphorylation, and enzyme reactions (99). It has been proposed that the phenolics thymol and carvacrol inhibit Gram-negative bacteria by disrupting the outer cell membrane and decreasing the concentration gradient (42). EO may cause changes in the archaeal community structure, decreasing methanogen abundance, some protozoa species, and methane production up to $37 \%$, the challenge is finding the appropriate essential oil which minimize the decrease in feed degradation (98). In vitro experiments have been encouraging using thymol, carvacrol, cinnamaldehyde, and allicin, limonene and in vivo Xtract ${ }^{\circledR} 6965$, rosemary, cinnamaldehyde, anise, garlic, juniper berry, capsicum, $\operatorname{ropadiar}^{\circledR}$, eugenol, crina ${ }^{\circledR}$ blends among others. Mohammed et al. (100) were able to decrease $\mathrm{CH}_{4}$ emissions by $19 \%$ in steers fed $\alpha$-cyclodextrin-horseradish oil complex as a methane-suppressing component. However, Benchaar (101) found no effect of oregano oil and carvacrol on enteric $\mathrm{CH}_{4}$ emissions when fed $(50 \mathrm{mg} / \mathrm{kg} \mathrm{DM})$ to dairy cows, Belanche et al. (102) found a decrease in methane emissions when they fed Agolin Ruminant ${ }^{\circledR}$ (essential oils blend) to dairy cows, similarly Castro-Montoya et al. (103) also found a reduction in enteric $\mathrm{CH}_{4}$ emissions in dairy cows fed Agolin Ruminant ${ }^{\circledR}$ in the ration during 6 weeks of supplementation.

$\mathrm{Wu}$ et al. (104) reported that intermittent feeding of citrus essential oils (d-limonene) has potential to mitigate $\mathrm{CH}_{4}$ emissions in $\mathrm{Hu}$ sheep by reducing microbial adaptation. $\mathrm{Du}$ Han hybrid sheep housed in open-circuit respiration chambers decreased enteric $\mathrm{CH}_{4}$ emissions when they were supplemented with essential anise oil, probably because of the effect of the oil on the rumen microbial population (105). It remains to be seen the potential of EO for $\mathrm{CH}_{4}$ mitigation under commercial, practical conditions in cattle and sheep farms. Citrus by-products are widely used as energy supplements during the dry season in many tropical countries with good results in animal performance $(106,107)$. It is of special attention that some essential oils elicit feed consumption due to the aroma they add to the ration and in some other cases negatively affect palatability, as in the case of garlic oil (108). Further trials are needed, to consider the use of essential oils as a commercial option at farm level, learn about the interactions of the active compounds with the ingredients of the ration and their capacity against specific methanogens should be identified without affecting other groups of microorganisms in the rumen, so as not to alter fermentation pattern and rumen degradability, as well as the different doses for each essential oil, the persistence of the enteric 
$\mathrm{CH}_{4}$ mitigating, the possible increase in production and its economic benefits.

\section{FLAVONOIDS}

Flavonoids are polyphenols with the C6-C3-C6 skeleton, derivatives of benzo-L-pyrone $(109,110)$ which are found in seeds and vegetables and display anti-inflammatory, antioxidative, and antimicrobial properties and interfere with different bactericidal factors, including enzymes, toxins, and signal receptors (111) and potential to improve animal welfare. Flavonoids can be generally classified on the basis of their molecular structure and are grouped into eight different flavonoid groups: flavanol, flavandiol, flavanone, dihydroflavonol, flavone, flavonol, isoflavone, and anthocyanidin [(112); Figure 4].

Flavonoids are well-known to be beneficial during periods of animal stress, balance rumen $\mathrm{pH}$ in subacute acidosis, reduce the inflammatory state of high grain diets, and for their antibacterial activity which depends on their chemical structure particularly on the substitutions on the aromatic rings (41). Flavonoids exert their effect against Gram-positive microorganisms by inhibiting the function of the cytoplasmic membrane, inhibiting the synthesis of the bacterial cell wall, or by inhibition of nucleic acid synthesis. Flavonoids have been proposed for incorporation in ruminant rations to improve productivity through an increase in the production of propionate relative to acetate (41). Oskoueian et al. (56) reported that the flavonoid naringin and quercetin reduced methane production, ciliate protozoa, and hydrogenotrophic methanogens in vitro.

Seradj et al. (53) found that a commercial citrus extract of flavonoids blend (Bioflavex ${ }^{\circledR}$ ) reduced methane production, the population of hydrogenotrophic methanogenic archaea and increased the concentration of propionate and the population of Megasphaera elsdenii in vitro. Stoldt et al. (47) found that rutin (glucrohamnoside of quercetin) had no effect on methane production or energy metabolism of Holstein cows housed in respiration chambers. Cui et al. (113) reported that the addition of $3.0 \mathrm{mg}$ rutin/ $\mathrm{kg}$ to diets on multiparous Chinese Holstein cows increased milk yield $(10.06 \%)$ in the long term and improved metabolism and digestibility of dairy cows. Other experiments using Holstein cows and supplementation of 60 $\mathrm{mg} / \mathrm{kg}$ body weight of alfalfa flavonoid extract increased the valeric acid:total volatile fatty acid ratio, the composition of milk, nutrient digestion, and had a tendency to increase the population of Butyrivibrio fibrisolvens (114). Recently, Sinz et al. (55) under in vitro conditions found that the flavonoid luteolin-7-glucoside did reduce methane. It seems from the data available that flavonoids show potential for methane mitigation but further research in trials carried out in vivo are necessary.

The results found with the use of secondary metabolites for the reduction in methane synthesis are variable and dependent on the type of the metabolite, its characteristics and the ration. It is also necessary to verify their effect on methane production in long-term in vivo trials due to the possible adaptation of rumen microorganisms to the metabolite and the differences presented between in vitro and in vivo trials.

\section{TROPICAL PLANTS CONTAINING SECONDARY METABOLITES AS A CH MITIGATION STRATEGY FOR SMALLHOLDERS}

There are considerable challenges ahead for small livestock keepers in the way toward sustainable intensification of animal agriculture in developing countries (115-117). Enteric $\mathrm{CH}_{4}$ emissions originating from ruminant species have been accumulating in the atmosphere from decades ago, with the greatest increase originating from cattle in developing countries, probably because of the rise in animal numbers (118). In the present review, the potential of tropical trees and shrubs (21) to lead the way toward sustainable intensification of ruminant production has been emphasized with data from experiments carried out in developing countries. Some of the important issues to move one step ahead from laboratory experiments to on-farm application of results, are: fair access to markets for smallholders, organization of smallholders (i.e., cooperatives), access to credits and financing, technical support, incorporation of added value to products, development of sustainable value chains $(119,120)$. Small livestock keepers in developing countries actually use a range of tropical plants (i.e., legumes) to feed their animals on a daily basis, particularly in the dry season and therefore, they are mitigating enteric $\mathrm{CH}_{4}$ emissions at present without actually being aware of it. It is responsibility of those in office at agricultural ministries, international agencies $(119,120)$ or in universities (121) to make this clear to the general public and to decision makers in their areas of influence. It is also important to eliminate the distortions in agricultural policy which unfairly favor economies of scale (large producers) against small livestock keepers. There is great potential to mitigate enteric $\mathrm{CH}_{4}$ emissions in the cattle sector in developing countries with a concomitant improvement in productivity and livelihoods of the poor (122-124). Novel approaches in public policies through incentives (tax and trading schemes) for producers applying $\mathrm{CH}_{4}$ mitigation practices at farms, may be worth testing in developing countries for widespread adoption (125). Although, it is also highly advisable to improve on the methane inventories of regions or indeed countries from Tier I, to higher levels (i.e., Tier II) of accuracy (126) before any $\mathrm{CH}_{4}$ mitigation strategy is put into effect on the field.

\section{CONCLUDING REMARKS}

Ruminant production systems will face tremendous challenges in the next forthcoming years due to the increasing demand for beef and milk by the burgeoning population. Climate change (floods, droughts, hail storms) and disease (Covid-19) are imposing a severe negative impact on the health status and economic 
wellbeing of millions of smallholders in developing countries. Undernutrition is growing rampant in many Latin American countries, particularly in rural areas. Sustainable intensification of ruminant production is a prerequisite to accomplish the ambitious GHG mitigation goals set by national governments to comply with international agreements. There is a need to reduce emissions of greenhouses gases from ruminant production systems while increasing energetic efficiency of protein and fat synthesis in the whole body and in the mammary gland. The ample array of plant secondary metabolites with methanesuppressing potential will have a role to play regarding mitigation of enteric $\mathrm{CH}_{4}$ under practical farming conditions in tropical countries with smallholders. Usually, PSM such as tannins, saponins, essential oils, and flavonoids act either by affecting directly methanogenic archaea or indirectly by disrupting the membrane of rumen protozoa. Some secondary metabolites also increase molar proportions of propionic acid in the rumen, thus rechannelling $\mathrm{H}_{2}$ away from methanogenesis toward synthesis of propionic acid. In the tropics, supplementation with foliage, pods, tubers, seeds of a range of tropical species seems a rational, and practical approach for enteric methane mitigation under the conditions of small-scale ruminant production systems. Browses and pods of tropical plant species supply rumen fermentable nitrogen for the microbial population, thus improving microbial protein synthesis and degradation of fermentable organic matter in the rumen, a main driver for productivity in ruminant species. As we advance in our understanding of the mechanisms by which secondary metabolites alter rumen fermentation, it is of paramount importance to understand the interplay between the supply of those metabolites, the rumen microbiome and methanogenesis so as to maximize feed efficiency, one of the most important features of financial profitability in ruminant production.

\section{REFERENCES}

1. Delgado CL, Rosegrant MW, Steinfeld H, Ehui SK, Courbois C, International Food Policy Research Institute, FAO, International Livestock Research Institute (editors). Livestock to 2020: The Next Food Revolution. Washington, DC (1999).

2. Beauchemin KA, Ungerfeld EM, Eckard RJ, Wang M. Review: fifty years of research on rumen methanogenesis: lessons learned and future challenges for mitigation. Animal. (2020) 14:s2-16. doi: 10.1017/S1751731119003100

3. IPCC ed. Introduction. In: Climate Change 2013: The Physical Science Basis. Contribution of Working Group I to the Fifth Assessment Report of the Intergovernmental Panel on Climate Change. Cambridge;New York, NY: Cambridge University Press (2013).

4. Ali AIM, Wassie SE, Korir D, Goopy JP, Merbold L, Butterbach-Bahl $\mathrm{K}$, et al. Digesta passage and nutrient digestibility in Boran steers at low feed intake levels. J Animal Physiol Animal Nutr. (2019) 103:132537. doi: $10.1111 /$ jpn. 13158

5. Goopy JP, Korir D, Pelster D, Ali AIM, Wassie SE, Schlecht E, et al. Severe below-maintenance feed intake increases methane yield from enteric fermentation in cattle. $\mathrm{Br} J$ Nutr. (2020) 123:1-8. doi: 10.1017/S0007114519003350

6. Firkins JL, Yu Z. Ruminant nutrition symposium: how to use data on the rumen microbiome to improve our understanding of ruminant nutrition. J Animal Sci. (2015) 93:1450-70. doi: 10.2527/jas.201 $4-8754$

\section{AUTHOR CONTRIBUTIONS}

JK-V, RJ-O, SV-S, MM-F, and IM-B writing the manuscript. $\mathrm{JA}$ and JK-V leaders of the grants. CG-B, FS-S, JA, and CA-P edited the final version of the manuscript. All authors contributed to manuscript revision, intellectual content, and approved the manuscript for publication.

\section{FUNDING}

This work was implemented as part of the CGIAR Research Programs on Livestock and Climate Change, Agriculture and Food Security (CCAFS), which are carried out with support from CGIAR Fund Donors and through bilateral funding agreements. For details please visit https://ccafs.cgiar.org/donors. The views expressed in this document cannot be taken to reflect the official opinions of these organizations. We thank all donors that globally support our work through their contributions to the CGIAR system.

\section{ACKNOWLEDGMENTS}

We are indebted to CONACYT-Mexico for granting several MSc, Ph.D., and postdoctoral fellowships to Mexican and foreign students at the Laboratory of Climate Change and Livestock Production, University of Yucatan, Mexico; and for financial support to keep the respiration chambers running. RJ-O and SV-S are deeply grateful with the CLIFF-GRADS Programme, a joint effort from CCAFS and the Global Research Alliance on Agricultural Greenhouse Gases (www.globalresearchalliance.org), for the opportunity of strengthening their research skills and capabilities.
7. Cammack KM, Austin KJ, Lamberson WR, Conant GC, Cunningham HC. Tiny but mighty: the role of the rumen microbes in livestock production. $J$ Anim Sci. (2018) 96:752-70. doi: 10.1093/jas/skx053

8. Vasta V, Daghio M, Cappucci A, Buccioni A, Serra A, Viti C, et al. Invited review: plant polyphenols and rumen microbiota responsible for fatty acid biohydrogenation, fiber digestion, and methane emission: experimental evidence and methodological approaches. J Dairy Sci. (2019) 102:3781804. doi: 10.3168/jds.2018-14985

9. Aboling S, Drotleff AM, Cappai MG, Kamphues J. Contamination with ergot bodies (Claviceps purpurea sensu lato) of two horse pastures in Northern Germany. Mycotoxin Res. (2016) 32:207-19. doi: 10.1007/s12550-016-0253-y

10. Ørskov ER, Flatt WP, Moe PW. Fermentation balance approach to estimate extent of fermentation and efficiency of volatile fatty acid formation in ruminants. J Dairy Sci. (1968) 51:142935. doi: 10.3168/jds.S0022-0302(68)87208-X

11. Huws SA, Creevey CJ, Oyama LB, Mizrahi I, Denman SE, Popova M, et al. Addressing global ruminant agricultural challenges through understanding the rumen microbiome: past, present, and future. Front Microbiol. (2018) 9:2161. doi: 10.3389/fmicb.2018.02161

12. O'Hara E, Neves ALA, Song Y, Guan LL. The role of the gut microbiome in cattle production and health: driver or passenger? Ann Rev Anim Biosci. (2020) 8:199-220. doi: 10.1146/annurev-animal-021419-083952

13. Chen J, Harstad OM, McAllister T, Dörsch P, Holo H. Propionic acid bacteria enhance ruminal feed degradation and reduce methane production in vitro. Acta Agri Scand. (2020) 69:1-7. doi: 10.1080/09064702.2020.1737215 
14. Kittelmann S, Pinares-Patiño CS, Seedorf H, Kirk MR, Ganesh S, McEwan JC, et al. Two different bacterial community types are linked with the low-methane emission trait in sheep. PLOS ONE. (2014) 9:e103171. doi: 10.1371/journal.pone.0103171

15. Lan W, Yang C. Ruminal methane production: associated microorganisms and the potential of applying hydrogen-utilizing bacteria for mitigation. Sci Total Environ. (2019) 654:1270-83. doi: 10.1016/j.scitotenv.2018.11.180

16. Delgado B, Bach A, Guasch I, González C, Elcoso G, Pryce JE, et al. Whole rumen metagenome sequencing allows classifying and predicting feed efficiency and intake levels in cattle. Sci Rep. (2019) 9:11. doi: 10.1038/s41598-018-36673-w

17. Cunha CS, Marcondes MI, Veloso CM, Mantovani HC, Pereira LGR, Tomich TR, et al. Compositional and structural dynamics of the ruminal microbiota in dairy heifers and its relationship to methane production. J Sci Food Agr. (2019) 99:210-8. doi: 10.1002/jsfa.9162

18. Global Rumen Census Collaborators, Henderson G, Cox F, Ganesh S, Jonker A, Young W, et al. Rumen microbial community composition varies with diet and host, but a core microbiome is found across a wide geographical range. Sci Rep. (2015) 5:14567. doi: 10.1038/srep 14567

19. Topps JH. Potential, composition and use of legume shrubs and trees as fodders for livestock in the tropics. J Agr Sci. (1992) 118:18. doi: $10.1017 /$ S0021859600067940

20. Ku Vera JC, Ramírez Avilés, Jiménez-Ferrer, Alayon-Gamboa, RamírezCancino. Árboles y arbustos para la producción animal en el trópico mexicano. In: Agroforestería Para la Producción Animal en América Latina. Rome: FAO Food and Agriculture Organization of the United Nations (2019). p. 231-57.

21. Vandermeulen S, Ramírez-Restrepo CA, Beckers Y, Claessens H, Bindelle J. Agroforestry for ruminants: a review of trees and shrubs as fodder in silvopastoral temperate and tropical production systems. Anim Product Sci. (2018) 58:767. doi: 10.1071/AN16434

22. Shelton M, Dalzell S. Production, economic and environmental benefits of leucaena pastures. Trop Grasslands. (2007) 41:174-90.

23. Makkar HPS, Francis G, Becker K. Bioactivity of phytochemicals in some lesser-known plants and their effects and potential applications in livestock and aquaculture production systems. Animal. (2007) 1:137191. doi: $10.1017 /$ S1751731107000298

24. Benchaar C, Calsamiglia S, Chaves AV, Fraser GR, Colombatto D, McAllister TA, et al. A review of plant-derived essential oils in ruminant nutrition and production. Anim Feed Sci Technol. (2008) 145:20928. doi: 10.1016/j.anifeedsci.2007.04.014

25. Patra A, Saxena J. The effect and mode of action of saponins on the microbial populations and fermentation in the rumen and ruminant production. Nut Res Rev. (2009) 22:204-19. doi: 10.1017/S0954422409990163

26. Patra A, Park T, Yu Z. Rumen methanogens and mitigation of methane emission by anti-methanogenic compounds and substances. J Anim Sci Biotechnol. (2017) 8:13. doi: 10.1186/s40104-017-0145-9

27. Newbold CJ, El Hassan SM, Wang J, Ortega ME, Wallace RJ. Influence of foliage from African multipurpose trees on activity of rumen protozoa and bacteria. Br J Nut. (1997) 78:237-49. doi: 10.1079/BJN19970143

28. Kamra DN, Singh B. Rumen microbiome Plant Secondary Metabolites (PSM): inhibition of methanogenesis improving nutrient utilization. In: Satyanarayana T, Deshmukh SK, Deshpande MV, editors. Advancing Frontiers in Mycology \& Mycotechnology. Singapore: Springer Singapore (2019). p. 325-45. doi: 10.1007/978-981-13-9349-5_13

29. Kamra DN. Rumen microbial ecosystem. Curr Sci. (2005) 81:124-35.

30. Liu Y, Whitman WB. Metabolic, phylogenetic, and ecological diversity of the methanogenic archaea. Ann NY Acad Sci. (2008) 1125:17189. doi: 10.1196/annals.1419.019

31. Van Soest PJ. Nutritional Ecology of the Ruminant. Ithaca, NY: Cornell University Press (1994).

32. Malik PK, Kolte AP, Baruah L, Saravanan M, Bakshi B, Bhatta R. Enteric methane mitigation in sheep through leaves of selected tanniniferous tropical tree species. Livestock Sci. (2017) 200:29-34. doi: 10.1016/j.livsci.2017.04.001

33. Schäfer G, Engelhard M, Müller V. Bioenergetics of the Archaea. Microbiol Mol Biol Rev. (1999) 63:570-620. doi: 10.1128/MMBR.63.3.570-620.1999

34. Czerkawski JW. An Introduction to Rumen Studies. New York, NY: Pergamon Press. (1986). doi: 10.1016/B978-0-08-025486-9.50007-4
35. Warner D, Bannink A, Hatew B, van Laar H, Dijkstra J. Effects of grass silage quality and level of feed intake on enteric methane production in lactating dairy cows1. J Anim Sci. (2017) 95:3687-99. doi: 10.2527/jas.2017.1459

36. IPCC. 2006 IPCC guidelines for national greenhouse gas inventories. In: Eggleston HS, Buendia L, Miwa K, Ngara T, Tanabe K, editors. Prepared by the National Greenhouse Gas Inventories Programme. IGES (2006).

37. van Lingen HJ, Plugge CM, Fadel JG, Kebreab E, Bannink A, Dijkstra J. Thermodynamic driving force of hydrogen on rumen microbial metabolism: a theoretical investigation. PLOS ONE. (2016) 11:e0161362. doi: 10.1371/journal.pone.0161362

38. Cantalapiedra-Hijar G, Abo-Ismail M, Carstens GE, Guan LL, Hegarty R, Kenny DA, et al. Review: Biological determinants of between-animal variation in feed efficiency of growing beef cattle. Animal. (2018) 12:s32135. doi: 10.1017/S1751731118001489

39. Sarwar Gilani G, Wu Xiao C, Cockell KA. Impact of antinutritional factors in food proteins on the digestibility of protein and the bioavailability of amino acids and on protein quality. Br J Nut. (2012) 108:S31532. doi: $10.1017 /$ S0007114512002371

40. Naumann HD, Tedeschi LO, Zeller WE, Huntley NF. The role of condensed tannins in ruminant animal production: advances, limitations and future directions. Revista Brasileira de Zootecnia. (2017) 46:92949. doi: 10.1590/s1806-92902017001200009

41. Olagaray KE, Bradford BJ. Plant flavonoids to improve productivity of ruminants - A review. Anim Feed Sci Technol. (2019) 251:2136. doi: 10.1016/j.anifeedsci.2019.02.004

42. Cobellis G, Trabalza-Marinucci M, Yu Z. Critical evaluation of essential oils as rumen modifiers in ruminant nutrition: A review. Sci Total Environ. (2016) 545-546:556-8. doi: 10.1016/j.scitotenv.2015.12.103

43. Xie Y, Yang W, Tang F, Chen X, Ren L. Antibacterial activities of flavonoids: structure-activity relationship and mechanism. Curr Med Chem. (2014) 22:132-49. doi: 10.2174/0929867321666140916113443

44. Montoya-Flores MD, Molina-Botero IC, Arango J, Romano-Muñoz JL, Solorio-Sánchez FJ, Aguilar-Pérez CF, et al. Effect of dried leaves of Leucaena leucocephala on rumen fermentation, rumen microbial population, and enteric methane production in crossbred heifers. Animals. (2020) 10:300. doi: 10.3390/ani10020300

45. Valencia Salazar SS, Piñeiro Vázquez AT, Molina Botero IC, Lazos Balbuena FJ, Uuh Narváez JJ, Segura Campos MR, et al. Potential of Samanea saman pod meal for enteric methane mitigation in crossbred heifers fed low-quality tropical grass. Agri Forest Meteorol. (2018) 258:10816. doi: 10.1016/j.agrformet.2017.12.262

46. Molina-Botero IC, Montoya-Flores MD, Zavala-Escalante LM, BarahonaRosales R, Arango J, Ku-Vera JC. Effects of long-term diet supplementation with Gliricidia sepium foliage mixed with Enterolobium cyclocarpum pods on enteric methane, apparent digestibility, and rumen microbial population in crossbred heifers. J Anim Sci. (2019) 97:1619-33. doi: 10.1093/jas/s kz067

47. Stoldt A-K, Derno M, Das G, Weitzel JM, Wolffram S, Metges CC. Effects of rutin and buckwheat seeds on energy metabolism and methane production in dairy cows. J Dairy Sci. (2016) 99:2161-8. doi: 10.3168/jds.2015-10143

48. Molina IC, Angarita EA, Mayorga OL, Chará J, Barahona-Rosales R. Effect of Leucaena leucocephala on methane production of Lucerna heifers fed a diet based on Cynodon plectostachyus. Livestock Sci. (2016) 185:249. doi: 10.1016/j.livsci.2016.01.009

49. Patra A, Kamra DN, Bhar R, Kumar R, Agarwal N. Effect of Terminalia chebula and Allium sativum on in vivo methane emission by sheep: methane inhibition in sheep by plant feed additives. J Anim Physiol Anim Nutr. (2011) 95:187-91. doi: 10.1111/j.1439-0396.2010.01039.x

50. Abdalla AL, Louvandini H, Sallam SMAH, Bueno IC da S, Tsai $\mathrm{SM}$, Figueira $\mathrm{AV}$ de $\mathrm{O}$. In vitro evaluation, in vivo quantification, and microbial diversity studies of nutritional strategies for reducing enteric methane production. Trop Anim Health Product. (2012) 44:95364. doi: 10.1007/s11250-011-9992-0

51. Wanapat M, Chanthakhoun V, Phesatcha K, Kang S. Influence of mangosteen peel powder as a source of plant secondary compounds on rumen microorganisms, volatile fatty acids, methane and microbial protein synthesis in swamp buffaloes. Livestock Sci. (2014) 162:12633. doi: $10.1016 /$ j.livsci.2014.01.025 
52. Anantasook N, Wanapat M, Cherdthong A. Manipulation of ruminal fermentation and methane production by supplementation of rain tree pod meal containing tannins and saponins in growing dairy steers. J Anim Physiol Anim Nutr. (2014) 98:50-5. doi: 10.1111/jpn.12029

53. Seradj AR, Abecia L, Crespo J, Villalba D, Fondevila M, Balcells J. The effect of Bioflavex $(\mathbb{R})$ and its pure flavonoid components on in vitro fermentation parameters and methane production in rumen fluid from steers given high concentrate diets. Anim Feed Sci Technol. (2014) 197:8591. doi: 10.1016/j.anifeedsci.2014.08.013

54. Abarghuei MJ, Rouzbehan Y, Salem AZM, Zamiri MJ. Nutrient digestion, ruminal fermentation and performance of dairy cows fed pomegranate peel extract. Livestock Sci. (2013) 157:452-61. doi: 10.1016/j.livsci.2013.09.007

55. Susanne S, Carmen K, Annette L, Ueli B, Svenja M, Carla RS, et al. In vitro bioactivity of various pure flavonoids in ruminal fermentation, with special reference to methane formation. Czech J Anim Sci. (2018) 63:293304. doi: 10.17221/118/2017-CJAS

56. Oskoueian E, Abdullah N, Oskoueian A. Effects of flavonoids on rumen fermentation activity, methane production, and microbial population. BioMed ResInt. (2013) 2013:1-8. doi: 10.1155/2013/349129

57. Kim ET, Guan LL, Lee SJ, Lee SM, Lee SS, Lee ID, et al. Effects of flavonoid-rich plant extracts on in vitro ruminal methanogenesis, microbial populations and fermentation characteristics. Asian-Australasian J Anim Sci. (2015) 28:530-7. doi: 10.5713/ajas.14.0692

58. Al-Sagheer AA, Elwakeel EA, Ahmed MG, Sallam SMA. Potential of guava leaves for mitigating methane emissions and modulating ruminal fermentation characteristics and nutrient degradability. Environ Sci Pollut Res. (2018) 25:31450-58. doi: 10.1007/s11356-018-3152-2

59. Cherdthong A, Khonkhaeng B, Foiklang S, Wanapat M, Gunun N, Gunun P, et al. Effects of supplementation of piper sarmentosum leaf powder on feed efficiency, rumen ecology and rumen protozoal concentration in thai native beef cattle. Animals. (2019) 9:130. doi: 10.3390/ani9040130

60. Ramos-Morales E, Rossi G, Cattin M, Jones E, Braganca R, Newbold CJ. The effect of an isoflavonid-rich liquorice extract on fermentation, methanogenesis and the microbiome in the rumen simulation technique. FEMS Microbiol Ecol. (2018) 94: fiy009. doi: 10.1093/femsec/fiy009

61. Jafari S, Goh YM, Rajion MA, Jahromi MF, Ahmad YH, Ebrahimi M. Papaya Carica papaya leaf methanolic extract modulates in vitro rumen methanogenesis and rumen biohydrogenation: effect of papaya leaf extract on rumen. Anim Sci J. (2017) 88:267-76. doi: 10.1111/asj.12634

62. Patra A, Yu Z. Effects of essential oils on methane production and fermentation by, and abundance and diversity of, rumen microbial populations. Appl Environ Microbiol. (2012) 78:427180. doi: 10.1128/AEM.00309-12

63. Giannenas I, Skoufos J, Giannakopoulos C, Wiemann M, Gortzi O, Lalas $S$, et al. Effects of essential oils on milk production, milk composition, and rumen microbiota in Chios dairy ewes. J Dairy Sci. (2011) 94:556977. doi: 10.3168/jds.2010-4096

64. Zhou R, Wu J, Lang X, Liu L, Casper DP, Wang C, et al. Effects of oregano essential oil on in vitro ruminal fermentation, methane production, and ruminal microbial community. J Dairy Sci. (2020) 103:230314. doi: $10.3168 /$ jds.2019-16611

65. Khorrami B, Vakili AR, Mesgaran MD, Klevenhusen F. Thyme and cinnamon essential oils: Potential alternatives for monensin as a rumen modifier in beef production systems. Animal Feed Science and Technology. (2015) 200:8-16. doi: 10.1016/j.anifeedsci.2014.11.009

66. Goel G, Makkar HPS. Methane mitigation from ruminants using tannins and saponins. Trop Anim Health Product. (2012) 44:72939. doi: 10.1007/s11250-011-9966-2

67. Ferreira D, Brandt EV, Coetzee J, Malan E. Condensed tannins. Prog Chem Org Nat Prod. (1999) 77:22-59. doi: 10.1007/978-3-7091-6366-5_2

68. Tavendale MH, Meagher LP, Pacheco D, Walker N, Attwood GT, Sivakumaran S. Methane production from in vitro rumen incubations with Lotus pedunculatus and Medicago sativa, and effects of extractable condensed tannin fractions on methanogenesis. Anim Feed Sci Technol. (2005) 123-124:403-19. doi: 10.1016/j.anifeedsci.2005.04.037

69. Mueller-Harvey, I. Unravelling the conundrum of tannins in animal nutrition and health. J Sci Food Agric. (2006) 86:2010-37. doi: $10.1002 /$ jsfa. 2577
70. Ramírez-Avilés L, Solorio-Sánchez FJ, Aguilar-Pérez CF, Ayala-Burgos AJ, Ku-Vera JC. Leucaena leucocephala feeding systems for cattle production in Mexico. Trop Grasslands-Forrajes Trop. (2019) 7:37580. doi: $10.17138 / \operatorname{tgft}(7) 375-380$

71. Harrison MT, McSweeney C, Tomkins NW, Eckard RJ. Improving greenhouse gas emissions intensities of subtropical and tropical beef farming systems using Leucaena leucocephala. Agr Syst. (2015) 136:13846. doi: 10.1016/j.agsy.2015.03.003

72. Saminathan M, Tan H, Sieo C, Abdullah N, Wong C, Abdulmalek E, et al. Polymerization degrees, molecular weights and protein-binding affinities of condensed tannin fractions from a Leucaena leucocephala hybrid. Molecules. (2014) 19:7990-8010. doi: 10.3390/molecules19067990

73. Suybeng B, Charmley E, Gardiner CP, Malau-Aduli BS, Malau-Aduli AEO. Methane emissions and the use of desmanthus in beef cattle production in Northern Australia. Animals. (2019) 9:542. doi: 10.3390/ani90 80542

74. Pal K, Patra A, Sahoo A, Kumawat PK. Evaluation of several tropical tree leaves for methane production potential, degradability and rumen fermentation in vitro. Livestock Sci. (2015) 180:98105. doi: 10.1016/j.livsci.2015.07.011

75. Manasri N, Wanapat $\mathrm{M}$, Navanukraw C. Improving rumen fermentation and feed digestibility in cattle by mangosteen peel and garlic pellet supplementation. Livestock Sci. (2012) 148:291-5. doi: 10.1016/j.livsci.2012.06.009

76. Rira M, Morgavi DP, Archimède H, Marie-Magdeleine C, Popova M, Bousseboua $\mathrm{H}$, et al. Potential of tannin-rich plants for modulating ruminal microbes and ruminal fermentation in sheep. J Anim Sci. (2015) 93:33447. doi: 10.2527/jas.2014-7961

77. Kalinowska M, Zimowski J, Paczkowski C, Wojciechowski ZA. The formation of sugar chains in triterpenoid saponins and glycoalkaloids. Phytochem Rev. (2005) 4:237-57. doi: 10.1007/s11101-0051422-3

78. Makkar HPS, Blümmel M, Becker K. In vitro effects of and interactions between tannins and saponins and fate of tannins in the rumen. J Sci Food Agri. (1995) 69:481-93. doi: 10.1002/jsfa.2740690413

79. Wallace R, McEwan NR, McIntosh FM, Teferedegne B, Newbold CJ. Natural products as manipulators of rumen fermentation. Asian-Australasian J Anim Sci. (2002) 15:1458-68. doi: 10.5713/ajas.2002.1458

80. Chen RJ, Chung T, Li F, Lin N, Tzen JT. Effect of sugar positions in ginsenosides and their inhibitory potency on $\mathrm{Na}+/ \mathrm{K}+$-ATPase activity. Acta Pharmacol Sinica. (2009) 30:61-9. doi: 10.1038/aps.2 008.6

81. Ramos-Morales E, Arco-Pérez A, Martín-García AI, Yáñez-Ruiz DR, Frutos $P$, Hervás $G$. Use of stomach tubing as an alternative to rumen cannulation to study ruminal fermentation and microbiota in sheep and goats. Anim Feed Sci Technol. (2014) 198:57-66. doi: 10.1016/j.anifeedsci.2014. 09.016

82. Wina E, Muetzel S, Becker K. The dynamics of major fibrolytic microbes and enzyme activity in the rumen in response to short- and long-term feeding of Sapindus rarak saponins. J Appl Microbiol. (2006) 100:11422. doi: 10.1111/j.1365-2672.2005.02746.x

83. Ojeda A, Barroso JA, Obispo N, Gil JL, Cegarra R. Composición química, producción de gas in vitro y astringencia en el follaje de Samanea saman (Jacq.) Merrill. Pastos y Forrajes. (2012) 35:205-18.

84. Jiménez-Hernández J, Meneses-Esparza F, Rosendo-Escobar J, Vivar-Vera MA, Bello-Pérez LA, García-Suárez FJ. Extracción y caracterización del almidón de las semillas de Enterolobium cyclocarpum extraction and characterization of starch from Enterolobium cyclocarpum seeds. CyTA - J Food. (2011) 9:89-95. doi: 10.1080/19476331003743626

85. Moscoso C, Vélez M, Flores A, Agudelo N. Effects of guanacaste tree (Enterolobium cyclocarpum Jacq. Griseb.) fruit as replacement for sorghum grain and cotton-seed meal in lamb diets. Small Ruminant Res. (1995) 18:121-4. doi: 10.1016/0921-4488(95)00677-D

86. Briceño-Poot EG, Ruiz-González A, Chay-Canul AJ, Ayala-Burgos AJ, Aguilar-Pérez CF, Solorio-Sánchez FJ, et al. Voluntary intake, apparent digestibility and prediction of methane production by rumen stoichiometry in sheep fed pods of tropical legumes. Anim Feed Sci Technol. (2012) 176:117-22. doi: 10.1016/j.anifeedsci.2012.07.014 
87. Ivan M, Koenig KM, Teferedegne B, Newbold CJ, Entz T, Rode LM, et al. Effects of the dietary Enterolobium cyclocarpum foliage on the population dynamics of rumen ciliate protozoa in sheep. Small Ruminant Res. (2004) 52:81-91. doi: 10.1016/S0921-4488(03)00230-X

88. Koenig KM, Ivan M, Teferedegne BT, Morgavi DP, Rode LM, Ibrahim IM, et al. Effect of dietary Enterolobium cyclocarpum on microbial protein flow and nutrient digestibility in sheep maintained fauna-free, with total mixed fauna or with Entodinium caudatum monofauna. Br J Nutr. (2007) 98:504-16. doi: 10.1017/S0007114507723930

89. Hess HD, Kreuzer M, Diaz TE, Lascano CE, Carulla JE, Soliva CR, et al. Saponin rich tropical fruits affect fermentation and methanogenesis in faunated and defaunated rumen fluid. Anim Feed Sci Technol. (2003) 109:7994. doi: 10.1016/S0377-8401(03)00212-8

90. Soliva CR, Zeleke AB, Clément C, Hess HD, Fievez V, Kreuzer M. In vitro screening of various tropical foliages, seeds, fruits and medicinal plants for low methane and high ammonia generating potentials in the rumen. Anim Feed Sci Technol. (2008) 147:53-71. doi: 10.1016/j.anifeedsci.2007. 09.009

91. Hart KJ, Yáñez-Ruiz DR, Duval SM, McEwan NR, Newbold CJ. Plant extracts to manipulate rumen fermentation. Anim Feed Sci Technol. (2008) 147:835. doi: 10.1016/j.anifeedsci.2007.09.007

92. Oni AO, Onwuka CFI, Oduguwa OO, Onifade OS, Arigbede OM. Utilization of citrus pulp based diets and Enterolobium cyclocarpum (JACQ. GRISEB) foliage by West African dwarf goats. Livestock Sci. (2008) 117:18491. doi: 10.1016/j.livsci.2007.12.010

93. Albores-Moreno S, Alayón-Gamboa JA, Ayala-Burgos AJ, Solorio-Sánchez FJ, Aguilar-Pérez CF, Olivera-Castillo L, et al. Effects of feeding ground pods of Enterolobium cyclocarpum Jacq. Griseb on dry matter intake, rumen fermentation, and enteric methane production by Pelibuey sheep fed tropical grass. Trop Anim Health Product. (2017) 49:85766. doi: 10.1007/s11250-017-1275-y

94. Ugbogu EA, Elghandour MMMY, Ikpeazu VO, Buendía GR, Molina OM, Arunsi UO, et al. The potential impacts of dietary plant natural products on the sustainable mitigation of methane emission from livestock farming. J Clean Product. (2019) 213:915-25. doi: 10.1016/j.jclepro.2018. 12.233

95. Szumacher-Strabel M, Cieślak A, Nowakowska A. Effect of oils rich in linoleic acid on in vitro rumen fermentation parameters of sheep, goats and dairy cows. J Anim Feed Sci. (2009) 18:440-52. doi: 10.22358/jafs/66419/2009

96. Dorman HJD, Deans SG. Antimicrobial agents from plants: antibacterial activity of plant volatile oils. J Appl Microbiol. (2000) 88:308-16. doi: 10.1046/j.1365-2672.2000.00969.x

97. Jouany J-P, Morgavi DP. Use of 'natural' products as alternatives to antibiotic feed additives in ruminant production. Animal. (2007) 1:144366. doi: 10.1017/S1751731107000742

98. Szumacher-Strabel M, Cieślak A. Potential of phytofactors to mitigate rumen ammonia and methane production. J Anim Feed Sci. (2010) 19:31937. doi: $10.22358 /$ jafs/66296/2010

99. Patra A (editor). Dietary Phytochemicals and Microbes. Dordrecht: Springer Netherlands (2012). doi: 10.1007/978-94-007-3926-0

100. Mohammed N, Ajisaka N, Lila ZA, Hara K, Mikuni K, Hara K, et al. Effect of Japanese horseradish oil on methane production and ruminal fermentation in vitro and in steers1. J Anim Sci. (2004) 82:183946. doi: $10.2527 / 2004.8261839 \mathrm{x}$

101. Benchaar C. Feeding oregano oil and its main component carvacrol does not affect ruminal fermentation, nutrient utilization, methane emissions, milk production, or milk fatty acid composition of dairy cows. J Dairy Sci. (2020) 103:1516-27. doi: 10.3168/jds.2019-17230

102. Belanche A, Newbold CJ, Morgavi DP, Bach A, Zweifel B, Yáñez-Ruiz DR. A meta-analysis describing the effects of the essential oils blend agolin ruminant on performance, rumen fermentation and methane emissions in dairy cows. Animals. (2020) 10:620. doi: 10.3390/ani10040620

103. Castro-Montoya J, Peiren N, Cone JW, Zweifel B, Fievez V, De Campeneere S. In vivo and in vitro effects of a blend of essential oils on rumen methane mitigation. Livestock Sci. (2015) 180:134-42. doi: 10.1016/j.livsci.2015.08.010

104. Wu P, Liu ZB, He WF, Yu SB, Gao G, Wang JK. Intermittent feeding of citrus essential oils as a potential strategy to decrease methane production by reducing microbial adaptation. J Clean Product. (2018) 194:70413. doi: $10.1016 /$ j.jclepro.2018.05.167

105. Wang B, Jia M, Fang L, Jiang L, Li Y. Effects of eucalyptus oil and anise oil supplementation on rumen fermentation characteristics, methane emission, and digestibility in sheep. J Anim Sci. (2018) 96:3460-70. doi: $10.1093 /$ jas/sky216

106. Bampidis VA, Robinson PH. Citrus by-products as ruminant feeds: a review. Anim Feed Sci Technol. (2006) 128:175217. doi: 10.1016/j.anifeedsci.2005.12.002

107. Faustino-Lázaro B, González-Reyna A, Bernal-Barragán H, GómezHernández L, Ibarra-Hinojosa M, Martínez-González J. Comportamiento productivo de corderas de pelo, alimentadas con pulpa fresca de limón como fuente energética. Rev MVZ Córdoba. (2016) 21:5480-9. doi: $10.21897 /$ rmvz. 822

108. Klevenhusen F, Zeitz JO, Duval S, Kreuzer M, Soliva CR. Garlic oil and its principal component diallyl disulfide fail to mitigate methane, but improve digestibility in sheep. Anim Feed Sci Technol. (2011) 166-167:35663. doi: 10.1016/j.anifeedsci.2011.04.071

109. Harborne JB, Williams CA. Advances in flavonoid research since 1992. Phytochemistry. (2000) 55:481-504. doi: 10.1016/S0031-9422(00)0 0235-1

110. Nijveldt RJ, van Nood E, van Hoorn DE, Boelens PG, van Norren $\mathrm{K}$, van Leeuwen PA. Flavonoids: a review of probable mechanisms of action and potential applications. Am J Clin Nutr. (2001) 74:41825. doi: 10.1093/ajcn/74.4.418

111. Cushnie TPT, Lamb AJ. Recent advances in understanding the antibacterial properties of flavonoids. Int J Antimicrob Agents. (2011) 38:99-107. doi: 10.1016/j.ijantimicag.2011.02.014

112. Halbwirth $H$. The creation and physiological relevance of divergent hydroxylation patterns in the flavonoid pathway. Int J Mol Sci. (2010) 11:595-621. doi: 10.3390/ijms1 1020595

113. Cui K, Guo XD, Tu Y, Zhang NF, Ma T, Diao QY. Effect of dietary supplementation of rutin on lactation performance, ruminal fermentation and metabolism in dairy cows. J Animal Physiol Anim Nutr. (2015) 99:106573. doi: $10.1111 /$ jpn. 12334

114. Zhan J, Liu M, Su X, Zhan K, Zhang C, Zhao G. Effects of alfalfa flavonoids on the production performance, immune system, and ruminal fermentation of dairy cows. Asian-Australasian J Anim Sci. (2017) 30:141624. doi: 10.5713/ajas.16.0579

115. McDermott JJ, Staal SJ, Freeman HA, Herrero M, Van de Steeg JA. Sustaining intensification of smallholder livestock systems in the tropics. Livestock Sci. (2010) 130:95-109. doi: 10.1016/j.livsci.2010.02.014

116. Thornton PK. Livestock production: recent trends, future prospects. Philos Trans R Soc B: Biol Sci. (2010) 365:2853-67. doi: 10.1098/rstb.201 0.0134

117. Herrero M, Grace D, Njuki J, Johnson N, Enahoro D, Silvestri S, et al. The roles of livestock in developing countries. Animal. (2013) 7:318. doi: $10.1017 /$ S1751731112001954

118. Dangal SRS, Tian H, Zhang B, Pan S, Lu C, Yang J. Methane emission from global livestock sector during 1890-2014: Magnitude, trends and spatiotemporal patterns. Global Change Biol. (2017) 23:414761. doi: $10.1111 / \mathrm{gcb} .13709$

119. Food and Agriculture Organization of the United Nations. Developing Sustainable Value Chains for Small-Scale Livestock Producers. Rome: Food and Agriculture Organization of the United Nations (2019).

120. World Economic Forum. Options for the Livestock Sector in Developing and Emerging Economies to 2030 and Beyond. Geneva: Switzerland (2019).

121. Leal Filho W, Morgan EA, Godoy ES, Azeiteiro UM, Bacelar-Nicolau P, Veiga Ávila L, et al. Implementing climate change research at universities: barriers, potential and actions. J Clean Product. (2018) 170:26977. doi: 10.1016/j.jclepro.2017.09.105

122. Herrero M, Henderson B, Havlík P, Thornton PK, Conant RT, Smith P, et al. Greenhouse gas mitigation potentials in the livestock sector. Nat Climate Change. (2016) 6:452-61. doi: 10.1038/nclimate2925

123. Kumari S, Fagodiya RK, Hiloidhari M, Dahiya RP, Kumar A. Methane production and estimation from livestock husbandry: a mechanistic understanding and emerging mitigation options. Sci 
Total Environ. (2020) 709:136135. doi: 10.1016/j.scitotenv.2019.1 36135

124. Salmon GR, MacLeod M, Claxton JR, Pica Ciamarra U, Robinson T, Duncan A, et al. Exploring the landscape of livestock 'Facts.' Global Food Security. (2020) 25:100329. doi: 10.1016/j.gfs.2019.1 00329

125. Key N, Tallard G. Mitigating methane emissions from livestock: a global analysis of sectoral policies. Climatic Change. (2012) 112:387414. doi: 10.1007/s10584-011-0206-6

126. Ndung'u PW, Bebe BO, Ondiek JO, Butterbach-Bahl K, Merbold L, Goopy JP. Improved region-specific emission factors for enteric methane emissions from cattle in smallholder mixed crop: livestock systems of Nandi County, Kenya. Anim Product Sci. (2019) 59:1136. doi: 10.1071/AN 17809
Conflict of Interest: The authors declare that the research was conducted in the absence of any commercial or financial relationships that could be construed as a potential conflict of interest.

The handling Editor declared a past co-authorship with one of the authors JK-V.

Copyright ๑ $2020 \mathrm{Ku}$-Vera, Jiménez-Ocampo, Valencia-Salazar, Montoya-Flores, Molina-Botero, Arango, Gómez-Bravo, Aguilar-Pérez and Solorio-Sánchez. This is an open-access article distributed under the terms of the Creative Commons Attribution License (CC BY). The use, distribution or reproduction in other forums is permitted, provided the original author(s) and the copyright owner(s) are credited and that the original publication in this journal is cited, in accordance with accepted academic practice. No use, distribution or reproduction is permitted which does not comply with these terms. 